\title{
LITERATURA MAGREBÍ EN EL EXILIO: RECREANDO IDENTIDAD
}

\author{
Eva Infante Mora
}

\begin{abstract}
The aim of this article is to analyse representative Franco-Maghrebian novels dealing with exile and to explore in them the interaction between Self and Other in the process of ethnic definitions. The characters in these novels carry with them a wide range of ethnic identities which are more or less salient depending on the circumstances and vis a vis various audiences. A study of the different meanings applied to the term "Arab" as well as the contexts in which this category is obscured in favour of other ethnic identities is undertaken. According to recent research, ethnicity is a constructionist dialectic played out by ethnic groups and the larger society. It involves a socially constructed, variable definition of Self and Other, whose existence and meaning are continuously negotiated, revised, and revitalized, both by ethnic group members themselves as well as by outside observers.
\end{abstract}

A diferencia de los movimientos migratorios del pasado, la diáspora post-industrial tiene lugar en un mundo donde incluso las antiguas convenciones geográficas y territoriales son cada vez más frágiles. Es por ello que las actuales migraciones no parecen tener orígenes definidos, destinos definitivos, ni identidades colectivas coherentes.

A. Ahmed y H. Donnan, "Islam in the age of postmodernity"1

Las principales cuestiones empíricas suscitadas por los movimientos de población contemporáneos giran en torno a problemas de identidad, autenticidad, y la vulnerabilidad que supone tener que redefinir el Yo en un mundo en constante cambio. La búsqueda de identidad se produce, particularmente, entre los que se encuentran en tierra extranjera pero también, en cierta medida, entre aquellos que permanecen atrás y descubren que su cultura, implantada en nuevos escenarios, comienza a ser definida y practicada de forma innovadora, a veces inquietante. Mientras la mayoría de los seres humanos son básicamente conscientes de una cultura, una comunidad y un hogar, el exiliado está obligado a aprehender varias realidades, a percibir dimensiones simultáneas. Con progresiva frecuencia en el mundo actual, el

\footnotetext{
${ }^{1}$ En A. S. Ahmed y H. Donnan (eds) Islam, Globalization and Postmodernity (London 1994) 4.
} 
fenómeno de la emigración significa desplazamiento físico a la vez que dislocación psicológica de una identidad inestable, resultado de la marginación cultural.

Ella nunca sabrá que entre los argelinos y nosotros, los A.N.I.s [Arabes No Identificados], hay tantas diferencias como entre yo mismo y mi imagen reflejada en un espejo. ${ }^{2}$

¿No habla la gente en todo el mundo de esos hombres que matan a los árabes en las ciudades francesas? ¿No has oído tú nada? Esos muchachos son tus hermanos, los árabes son tus hermanos. ¡Reacciona! ${ }^{3}$

Estos pasajes pertenecen a la denominada literatura francófona magrebí. El tema de la emigración desde el Norte de Africa hacia Europa es, desde la década de los cincuenta, frecuente entre los autores magrebíes residentes en Francia, y en el trasfondo de estas obras subyace la búsqueda de identidad de los personajes bajo las nuevas circunstancias del exilio. Como podemos ver en los anteriores pasajes, el proceso de identificación étnica se presenta como interacción y síntesis entre la autodefinición y la imposición ajena.

El objetivo de este artículo es ilustrar el diálogo entre el Yo y el Otro en el proceso de definición étnica con ejemplos extraídos de cuatro obras representativas de la literatura francófona magrebí que tratan del exilio. Las novelas estudiadas son Les Boucs de Driss Chraibi ${ }^{4}$ Parle mon fils parle a ta mere de Leila Sebbar, Les A.N.I. du 'Tassili' de Akli Tadjer y Zeida de Nulle Part de Leila Houari. ${ }^{5}$

\section{Recreando identidad: la etnia como constructo social}

La asimilación de minorías étnicas en el presente no es un proceso inexorable, como demuestran el fracaso de los programas de unificación en sociedades pluriculturales y el resurgir de los nacionalismos étnicos en Europa y África. La persistencia de diferencias culturales, lingüísticas y religiosas entre los pueblos desafía el antiguo concepto de etnia como forma vestigial de organización comunitaria susceptible de ser sustituida por otros factores de identificación más modernos como son la clase o el nacionalismo. La etnografía más temprana enfatiza una visión primordialista de la etnia demarcada principalmente por la lengua, la religión, la apariencia física o la procedencia geográfica. Según esta tendencia, la etnia posee profundas raíces históricas, su contenido es inmutable, y su forma pre-moderna. ${ }^{6}$

Actuamente, el estallido de conflictos de tipo étnico en el ámbito internacional ha propiciado la búsqueda de nuevas maneras, más exactas y menos evolucionistas, de interpretar no sólo el surgimiento de diferencias ancestrales entre los pueblos, sino también la emergencia de grupos étnicos históricamente nuevos. El resultado hasta el momento es el

\footnotetext{
${ }^{2}$ A. Tadjer, Les A.N.I. du 'Tassili' (Paris 1984) 175.

${ }^{3}$ L. Sebbar, Parle mon fils parle a ta mere (Paris 1984) 17.

${ }^{4}$ Paris 1955.

${ }^{5}$ Paris 1985.

${ }^{6} \mathrm{H}$. Isaacs, Idols of the Tribe: Group Identity and Political Change (New York 1975).
} 
desarrollo de un modelo de etnia definido como "instrumentalista", que subraya el carácter fluído, situacional, volicional y dinámico de la identificación, organización y acciones étnicas. ${ }^{7}$

Según esta tendencia, el origen, contenido y forma de la categoría "etnia" reflejan la elección creativa de individuos y grupos cuando se definen a sí mismos y a los demás como colectivo. Mediante acciones y descripciones mutuas de una variedad de grupos sociales -las etnias y sus antagónicos, autoridades políticas, grupos de intereses económicos y otros- se erigen las fronteras que afirman la comunalidad y los intereses del grupo, dividiendo unas poblaciones y uniendo otras.

Insistiendo en el caracter volicional del fenómeno, Karmela Liebkind describe la adscripción a una categoría étnica como el resultado de un "proceso de interacción contínua y dinámica entre el indivíduo y el Otro en donde la permuta de los esquemas de identificación -dentro y a través de las fronteras étnicas- puede modificar los esquemas personales y/o el sistema de valores de los individuos." ${ }^{8}$ En resumen, la identidad comprendería no sólo la visión que un indivíduo tiene de sí mismo sino también las ideas que el Otro expresa acerca de su grupo. Es una dialéctica entre opiniones y procesos internos y externos, entre la opción personal y la descripción ajena.

Edward W. Said se suma a la corriente instrumentalista al analizar la búsqueda de identidad y la redefinición de lealtades primordiales en su reciente libro Culture and Imperialism, ${ }^{9}$ donde afirma

Hoy en día nadie es puramente una sola cosa. Etiquetas como indio, mujer, musulmán o americano no son más que puntos de partida; así como los seres humanos construyen su propia historia, también recrean sus culturas e identidades étnicas. (...) El emigrante descubre en su marginalidad que la búsqueda de conceptos nuevos aún no adaptados a la norma general es la última esperanza del pensamiento (333).

Destacamos dos ideas: la relatividad de los conceptos "cultura" e "identidad", y la apertura de un discurso ajeno al sistema dominante, obscuro a la lógica del poder, que se presenta como única vía de escape para las minorías en peligro de asimilación: el que en algunas disciplinas ya se ha denominado "discurso del subalterno". ${ }^{10}$

En resumen, existe una fuerte tendencia entre los intelectuales de nuestro tiempo a concebir el concepto de identidad como un constructo condicionado no sólo por las coordenadas históricas sino también por el entorno social. Parece evidente que, a medida que el indivíduo se mueve en su vida cotidiana, su identidad étnica puede cambiar ante diferentes situaciones y audiencias. El contexto, pues, se eleva como factor esencial en este proceso.

\footnotetext{
${ }^{7}$ Y. Espiritu, Asian American Panethnicity: Bridging Institutions and Identities (Philadelphia 1992).

${ }^{8}$ New Identities in Europe. Immigrant Ancestry and the Ethnic Identity of Youth, European Science Foundation, (London 1989) 40.

${ }^{9}$ New York 1993.

${ }^{10}$ H. Guha y G. Spivak, Selected Subaltern Studies (Oxford 1988).
} 


\section{Contexto real y contextos literarios}

Entre 1967 y 1974 se produce en Francia una masiva llegada de inmigrantes procedentes del Norte de África, gracias a una campaña de reunificación familiar. Dos décadas después, estos hombres y mujeres son considerados como la "primera generación" de inmigrantes magrebíes residentes en Francia, mientras que sus hijos, nacidos y criados en el país de acogida, constituyen la "segunda generación" o beurs. Actualmente, la población magrebí en Francia se eleva a unos 4 millones de personas (el 7\% de la población francesa), incluyendo los nacidos en el Norte de África y su descendencia nacida en Francia. ${ }^{11}$

Los contextos proporcionados por las novelas determinan en gran medida la definición étnica de los personajes. En Les Boucs, Yaalan Waldik es un escritor que narra las miserias de sus compatriotas norteafricanos en Francia. Su obra es rechazada por los editores europeos, y el protagonista, desesperado, termina frecuentando los suburbios donde viven los trabajadores magrebíes. Tras un proceso de autodestrucción, Waldik se transforma en uno de los personajes miserables que él mismo muestra en sus libros. En Les A.N.I. du 'Tassili', Omar de la Garenne-Colombes, un beur que vuelve a Francia tras unas cortas vacaciones en Argelia (un período de adaptación voluntaria, como él mismo lo denomina), describe a la gente que conoce en el barco: inmigrantes norteafricanos, viajeros argelinos y turistas franceses, espectro representativo de las sociedades francesa y argelina. Parle mon fils parle a ta mere es una conversación entre una madre inmigrante y su hijo. Tras una larga ausencia, el hijo vuelve a la casa paterna situada en un barrio periférico parisino, y la madre le habla sobre su pasado en Argelia, la familia y los problemas de la vida en Francia, deseando que comparta sus preocupaciones y anhelos. El hijo, sin embargo, la escucha en silencio. Finalmente, Zeida de Nulle Part es la historia de una joven beur fascinada por sus raíces árabes. Con la esperanza de recobrar la vertiente oculta de su identidad, Zeida visita a su familia en Marruecos. Tras una breve estancia con ellos, la joven comprende que sus sueños de convertirse en una verdadera árabe nunca se cumplirán.

Sorprende al lector la gama de identidades que los personajes asumen o niegan en estas novelas, el despliegue de diferentes denominaciones étnicas que aparecen de forma más o menos explícita, dependiendo de las circunstancias y de los interlocutores. En este estudio vemos los diferentes significados que los personajes atribuyen a la categoría "árabe" y mostramos los contextos en los que esta identidad es oscurecida en favor de otras categorías étnicas, entre ellas "musulmán", "norteafricano" o "magrebí" y "beur". Las divergencias que surgen entre los personajes pertenecientes a la primera generación de inmigrantes y los beurs se explican como resultado de su diferente experiencia del exilio. A pesar de la variedad de argumentos, estas novelas comparten rasgos esenciales en la búsqueda de identidad, que analizamos siguiendo el esquema: a) identidad impuesta; b) identidad volicional; c) identidad recreada.

${ }^{11}$ G. Morin, "La Mosaïque des Français du Maghreb et des Maghrébins du France" en C. e Y. Lacoste (eds) L'Etat du Maghreb (Paris 1991) 533-537. 


\section{Identidad impuesta: la percepción del Otro.}

En las obras estudiadas observamos cómo la identidad se construye a partir de un enfrentamiento directo entre el Yo y el Otro, donde la auto-definición del personaje es matizada por estímulos externos. En les Boucs, Yaalan Waldik denuncia el rechazo de la sociedad francesa, cuya percepción lo persigue insistentemente:

Los oía con tanta frecuencia que se habían convertido en una especie de letanía. Sucio árabe, repetía el viento, y todos los demás nombres que los franceses usaban para mostrar su desprecio hacia nosotros: malfrat, arabe, crouillat, sidi, noraf..." (Chraibi:19).

A pesar de mostrarse fascinado por la cultura francesa al principio de la narración, el protagonista acaba despreciando una civilización cuya promesa de progreso aparece como una simple fachada tras la que se esconden violencia y explotación. Inicialmente ajeno a sus compatriotas obreros -él es un intelectual-, el contínuo enfrentamiento conduce a Waldik a identificarse con sus hermanos magrebíes, los "moros", y declara:

\footnotetext{
No trabajaré, deambularé por ahí, robaré, mataré...puesto que el mundo, Europa, los cristianos, no nos verán a nosotros, los sucios árabes, más que a través de un grueso cristal que han tenido que establecer, protegido con barras, y con un cartel que dice: ahí está el árabe, el verdadero árabe, el único (19).
}

Para los europeos Waldik no es especial, porque a simple vista sólo se trata de un "moro", indistinguible de la masa de norteafricanos que pueblan las ciudades francesas. El racismo, el hambre y la ira despiertan en él la solidaridad con sus compatriotas, y es entonces cuando deja de ser un indivíduo para convertirse en un ejemplo más de esa masa descrita por el Otro como "irracional y primitiva" (142). El discurso de Waldik, pleno de alusiones filosóficas al comienzo de la novela, se torna un reflejo de sus necesidades básicas, llegando a confesar que sólo le importan tres cosas: "su estómago, su habitación y su radio", y añadiendo además que "es posible encontrar lo que uno desea por instinto, como los animales"(148). Como vemos en estos ejemplos, Waldik toma conciencia de su pertenencia a la comunidad norteafricana a partir del rechazo que los franceses muestran hacia él y es entonces cuando la opinión del Otro se incorpora a la visión que el personaje tiene de sí mismo. Exhausto a causa de este conflicto de identidad, el protagonista acaba expresando: "Quiero beber y destruir en mí cualquier esperanza de redención y continuar siendo sólo un moro" (106).

En Parle mon fils se establece un diálogo entre madre e hijo. La madre representa el papel del Otro en este contexto, revelando la gran presión que la familia ejerce sobre los jóvenes beurs. Generalmente, en las familias inmigrantes se desarrollan fuertes lazos de dependencia emocional basados en la autoridad y es probable que, cuando los padres se identifican plenamente como miembros de un grupo étnico, se produzca un enfrentamiento con los hijos, que perciben un choque de lealtades entre la familia y sus propios intereses. En esta novela la madre lleva el peso de diálogo. El hijo interviene en contadas ocasiones, siendo su silencio una metáfora del difícil entendimiento entre dos generaciones que no comparten los mismos valores. En este contexto, la madre ejerce una contínua y agobiante imposición de identidad étnica sobre su hijo, de la que las siguientes frases son sólo una muestra: "las chicas de tu misma raza, ¿no te gustan? Y tu madre, tus hermanas, tus tías, tus primas, ¿te avergüenzas de ellas? ¿Por qué no una chica de tu propio país? Aunque no nacieras allí, aquél es tu país, no 
lo niegues, hijo mío, aquél es tu país" (774). A pesar de que el hijo no acaba de convencerse de las ventajas de ser magrebí en Europa, la presión del entorno familiar lo obliga a respetar sus raíces.

Akli Tadjer refleja la interacción Yo-Otro siempre que su protagonista, Omar, niega su identidad como respuesta a sucesivas provocaciones. Por ejemplo, cuando la intolerante oficial de aduanas se queja de que los inmigrantes declaran ser árabes aunque ni siquiera entienden la lengua árabe, él contesta: "Tiene razón, señora. Tenemos nombres árabes y somos morenos como ellos, sin embargo no somos verdaderos árabes" (15). En este pasaje, la actitud del Otro hace que Omar cuestione su identidad, introduciendo el problema de la autenticidad.

\section{El discurso del Otro}

El Otro pertenence a tres grupos diferenciados en las obras estudiadas: la sociedad francesa, miembros de la familia y compatriotas magrebíes no inmigrantes.

Occidente y la experiencia colonial son factores importantes a la hora de definir la propia identidad étnica. Como sostiene Akeel Bilgrami, "conformarse con la concepción que Occidente tiene de nosotros [los musulmanes] significa renunciar al punto de vista del agente y aceptar la idea de vernos como objetos, convirtiéndonos en seres pasivos ante sus ojos y ante nosotros mismos." ${ }^{12}$ La constatación de esta pasividad aparece en Les Boucs, novela que describe a la perfección el punto de vista de Occidente con respecto a los inmigrantes magrebíes: cuando Waldik conoce a un cabo francés, no puede evitar enfadarse con él, "a pesar de saber que no debía enfurecerse. A los cristianos les gusta la calma, el orden, la lógica. Un árabe pasivo con sus glándulas atrofiadas y su alma marchita no podía ser de ningún interés para aquel hombre" (Chraibi:22). Más tarde, hablando con el editor sobre su manuscrito, éste lo acusa de "no sólo comportarse como un pseudo-europeo, intentando destruir su concepto del típico árabe, sino también de olvidar que todo lo que le piden es que sea, simple y llanamente, un moro" (49). En resumidas cuentas, lo que el editor quiere es que Waldik "abandone sus pretensiones de imponer el Oriente sobre Europa" (ibid). En otro momento de la novela, el patrón de Waldik coincide con la visión general que Europa enarbola contra los inmigrantes magrebíes: "Eran la escoria. Entre los 300.000 árabes en Francia, ellos eran los deshechos, los parias (...). Habían abandonado sus almas al otro lado del Mediterráneo" (55).

El Occidente es también el Otro en Les A.N.I. du 'Tassili', encarnado por algunos turistas franceses con quienes Omar charla durante la travesía. Los estereotipos más frecuentes surgen en la conversación, y Omar se burla de ellos diciendo: "Conozco bien su letanía: tu país ... Tus raíces ... Tu bandera ... Tu padre ... Tu madre ... Tus hermanos ... Tus primos ... El cordero ... Vuestros dátiles ... Vuestros garbanzos ... La nostalgia" (73). Omar ironiza

12 "What is a Muslim? Fundamental Committment and Cultural Identity", Critical Inquiry 18-4 (Summer 1992) 837. 
sobre lo ridículo de las imágenes que Occidente mantiene sobre su cultura. Más adelante en la travesía, comprende que el discurso europeo sobre Oriente está lleno de "idées reçues y clichés surgidos de la observación de la realidad a través de cristales deformadores" (78). La conclusión de Omar se asemeja a la mención que Waldik realiza de "ese grueso cristal" a través del cual Europa mira a los árabes, como si fueran animales en una jaula (Chraibi:78). La impresión dominante es que el Oriente musulmán es visto por los europeos a través de lentes deformadoras, "conformando una percepción que hunde sus raíces en la imagen cristiana, franca, del mundo árabe-islámico, como si éste fuese la antítesis acabada de la civilización observante." ${ }^{13}$ En resumen, los pasajes anteriores reflejan la representación occidental del magrebí, el árabe en general, opinión que tiene su impacto en la propia definición que estos hombres y mujeres desarrollan de sí mismos.

Miembros del círculo familiar personifican al Otro en algunas novelas. En Parle mon fils la madre ejerce este papel, imponiendo la identidad árabe y musulmana sobre su hijo y justificando esta actitud en su convicción de que "las madres, las mujeres en general, son la memoria de la casa". (74). De hecho, la búsqueda de la identidad se suele inscribir en el ámbito de la lengua materna proyectada hacia el pasado simbólico de la cultura oral popular, cuya transmisión y preservación son aseguradas por las mujeres en el entorno doméstico.

Los compatriotas son la tercera encarnación del Otro, como ocurre en las novelas de Houari y Tadjer. En Zeida de Nulle Part, Watani, el amigo marroquí de Zeida, la convence de las diferencias insalvables que existen entre ella y las mujeres marroquíes. Según él, Zeida es la única persona que puede permitirse el lujo de soñar en un país donde la gente dejó de hacerlo. El sueño de Zeida es convertirse en una verdadera árabe y casarse con un beduíno. Sin embargo, a pesar de recrear su identidad libremente, no consigue desarrollar una relación íntima con Watani porque él la sigue considerando una europea. Es significativo que el hombre que Zeida ama se llame Watani, "mi país" en árabe. Zeida es rechazada por su propia cultura, su patria. De manera similar en Les A.N.I. los argelinos muestran su aversión por los viajeros inmigrantes, dejando patente en todo momento la distinción entre "argelinos de Argelia" e "inmigrantes argelinos". Un coronel argelino se dirige a Omar con las siguientes palabras: "Si fuérais verdaderos argelinos... pero sólo sois A.N.I.s, y esos dos viejos que están con vosotros no son más que fósiles de inmigración" (119). Más tarde, un estudiante argelino insiste en la distinción: "iNosotros tenemos conciencia! Pero vosotros, los A.N.I.s, un día tendréis que elegir entre Argelia y Francia. ¡No podréis seguir siendo toda vuestra vida unos adolescentes irresponsables, inconscientes e inmaduros!"(120).

Como hemos visto, la multiplicidad de definiciones étnicas que los personajes asumen en estas novelas se debe en gran medida a la variedad de interlocutores a los que los inmigrantes se enfrentan en los contextos literarios. El discurso del Otro, en su triple faceta de representación deformada (en el caso de Occidente), respuesta a la aculturación (de los

\footnotetext{
${ }^{13}$ V. Morales Lezcano, España Y Mundo Árabe. Imágenes Cruzadas (Madrid 1993) 57. Véase también E. Said, Orientalism (New York 1979).
} 
propios inmigrantes) y rechazo a la heterodoxia (por parte de los compatriotas en el país de origen) es neutralizado o incorporado por el personaje, dando lugar a designaciones alternativas.

\section{Identidad volicional: preservar el pasado}

En las auto-definiciones de los personajes encontramos algunas características comunes que se remiten al pasado, especialmente el orgullo de pertenecer a la comunidad étnica de origen y los recuerdos de la patria. En Les Boucs, Waldik declara: "Incluso si toda la creación del mundo occidental fuera a consumirse, yo diría: 'mis antepasados fueron árabes, y yo he vivido como un árabe, porque los encuentro profundamente entregados, no a una creencia o destino, sino a su miseria inmemorial'" (64). Lazos comunitarios y ascendencia común convergen en la mente de Waldik, siendo manifestaciones de vinculación usuales entre la primera generación de inmigrantes. La madre en Parle mon fils dice: "Yo también tengo un alma. Todos aquellos que creen en el Único Dios tienen alma. En cuanto a los demás, no lo sé" (56). De manera similar, los recuerdos del pasado salvan a la madre de Zeida del completo desarraigo. Admite que "vive en el pasado, pues éste es su historia y la recluye entre los cuatro húmedos muros de su casa" (Houari:39).

El sentimiento de pertenencia a la comunidad alcanza proporciones dramáticas en Les Boucs, donde Waldik confirma su deber inalienable de compartir y denunciar el sufrimiento de sus compatriotas los "norteafricanos". Él es, según nos dice, "un elemento en ese variado mosaico que las agencias de prensa denominan 'norteafricanos'" (71). Esta categoría tiene razones históricas: después de la Segunda Guerra Mundial, trabajadores procedentes de las colonias del Norte de África fueron contratados en masa para trabajar en la industria francesa. El mosaico al que Waldik alude estaba entonces formado por argelinos, marroquíes y tunecinos; árabes y beréberes; musulmanes y judíos. A pesar de esta diversidad étnica, estos inmigrantes fueron desde el principio vistos por la sociedad francesa como un grupo homogéneo de norteafricanos, clasificados en general como mano de obra no cualificada. A la larga, la percepción del Otro influye en la imagen que los magrebíes tienen de sí mismos.

No obstante, el uso de la categoría "norteafricano" por parte de Waldik se debe también a intereses propios: el personaje pretende unir a los inmigrantes magrebíes en un solo frente que sea capaz de luchar por su integración, consciente de que esta identidad no sólo alude a un origen geográfico común, sino también a un pasado de dominación francesa compartido, y a experiencias similares vividas en los procesos de independencia. La pertenencia a la comunidad norteafricana, por lo tanto, distingue a estos inmigrantes del resto de árabes y musulmanes que viven en Francia.

En general, las expresiones que definen la identidad volicional, en el caso de los inmigrantes de la primera generación, suelen estar llenas de símbolos guardados en la memoria colectiva. La preservación de los hábitos pasados y su puesta en práctica día a día salva a estos personajes del desarraigo en un país extraño. La pertenencia a la comunidad es un antídoto contra la aculturación en el exilio. Como contraste, cuando esta misma hipótesis 
se aplica al discurso de los beurs el resultado es discordante. Los inmigrantes magrebíes más jóvenes absorben desde su infancia tanto la cultura de sus padres como la cultura francesa. El pasado que sus padres invocan no existe para ellos más que como una serie de imágenes idealizadas, transmitidas oralmente por la familia o aprehendidas a partir del discurso del Otro. La identificación étnica es un proceso más complejo en su caso, pues "cúan diferente es que el nuevo inmigrante tenga que aprender a leer un texto histórico en préstamo, cuán diferente es hablar sobre el aprendizaje de una realidad étnica a estar afianzado en ella." ${ }^{14}$

La incapacidad de comprometerse con una única identidad es una variable repetida en las novelas con personajes beurs. Omar, después de haberse reconocido a sí mismo como A.N.I. o Árabe No Identificado, se manifiesta harto de "perseguir su 'arabicidad' como otros corren tras un filete de ternera" (Tadjer:186). La "arabicidad" cobra vida en esta novela y molesta constantemente al protagonista con sus preguntas. "Parece ignorar, piensa éste, la máxima A.N.I. eres, A.N.I. serás". Finalmente, Omar advierte que "uno no puede burlarse impunemente de un A.N.I. en busca de identidad" (187). Paradójicamente, el personaje experimenta la "arabicidad" como una cualidad ajena, generadora de conflicto, aun cuando el acrónimo que éste elige para definirse contiene en sí mismo la categoría "árabe".

Un problema añadido al proceso de definición es el hecho de que la mayoría de los beurs desconocen la lengua árabe. Karmela Liebkind afirma que los grupos modelan sus identidades a partir de sucesivas identificaciones, teniendo las más tempranas un impacto de supremacía sobre las demás. En otras palabras, si la lengua es un distintivo étnico en una sociedad multicultural, ésta será experimentada con toda probabilidad como fundamental en el proceso de identidad (242). La lengua (tanto el árabe como los dialectos beréberes) es un rasgo definitorio esencial para la primera generación de inmigrantes, que casi no hablan francés. La preocupación por conservar el árabe es expresada por la madre en Parle mon fils, cuando ésta confiesa preferir que su hijo se case con una mujer que pueda leer el Corán a sus hijos, al igual que Las Mil y Una Noches, en árabe (48). Sin embargo, su hijo sabe poco árabe, y ella lamenta su escaso interés por aprender "la lengua de sus ancestros, de su padre y de su madre, con el fin de leer y enseñar a sus hijos" (48).

\section{Identidad opcional: expectativas de futuro}

Hasta ahora, hemos prestado atención a aquellos símbolos y valores que se refieren al pasado de los personajes. En sus auto-definiciones, sin embargo, hay una segunda dimensión que concierne a las expectativas de futuro del inmigrante. Según Weinrich, "la identidad étnica comprende no sólo el estado actual del indivíduo, sino también la idea de un estado 'potencial'". ${ }^{15}$

Una diferencia radical se presenta de nuevo entre los personajes que pertenecen a la

${ }^{14}$ G. Spivak, "Acting Bits/Identity Talk", Critical Inquiry 18-4 (Summer 1992) 791.

15 "Conflicted Identifications: a Commentary on Identity Structure Analysis Concepts", en Liebkind (1989) 224. 
primera generación y los beurs. Los primeros viven con lo que algunos autores denominan el "mito del retorno" en sus mentes. Están seguros de que su estancia en Francia no es más que una permanencia pasajera, a pesar de los muchos obstáculos que impiden el cumplimiento de este sueño. A pesar de esto, el mito está presente en las novelas cada vez que aparece un miembro de esta generación. El regreso al hogar significa para ellos la completa reinserción en la sociedad de origen, puesto que Francia y los franceses no son más que un paréntesis en sus vidas. Esto explica que estos hombres y mujeres sufran las privaciones del exilio sin una señal de protesta, siempre con la vista puesta en el futuro. En Les Boucs, el editor expresa su satisfacción cuando lee el manuscrito de Waldik porque no encuentra en él rastro de odio o rebeldía. En él no hay más que "una falta de adaptación psicológica" (37). Según autores como Tahar ben Jelloun, los primeros inmigrantes magrebíes constituyen la denominada "generación del silencio". ${ }^{16}$

El mito del retorno afecta profundamente a algunos personajes, cuya principal preocupación será la preservación de aquellos valores y rasgos que le puedan facilitar la futura reinserción en sus sociedades de origen, especialmente los más amenazados por los intentos asimilacionistas franceses. Para muchos de ellos, absorber la cultura europea significa indudablemente convertirse en cristianos, puesto que ello conlleva la adaptación a una sociedad secular, aunque básicamente inspirada en la cultura cristiana católica. Por ello, la aserción de su identidad musulmana supone un vehículo de conexión con los países de origen. Así, por ejemplo, la madre en Parle mon fils se muestra orgullosa de ser musulmana: "será enterrado como un musulmán, hijo de musulmanes, no en el cementerio de los Infieles (...) sino en el pueblo de su abuelo paterno, incluso si eso lleva tiempo" (16). La identidad musulmana en este personaje implica también la identificación geográfica, la alusión al pueblo familiar como "Tierra de los Fieles" en contraposición a Europa, la "Tierra de los Infieles". El deseo de tener sepultura en un país musulmán proyecta la identidad de la madre hacia el futuro. Su hijo, en cambio, no mantiene especial relación con el Islam: aunque respeta los ritos y costumbres musulmanas, lo hace sólo en deferencia a sus padres, como él mismo confiesa: "como mi padre, realizo las abluciones, aunque no he rezado durante mucho tiempo (...) Me purifico como si fuera a rezar, pero ya no invoco a Dios en mis plegarias" (53). Evidentemente, la religión para este beur es un hábito desprovisto de significado o profundidad espiritual. La dimensión musulmana de su identidad es experimentada de manera distinta por los beurs, para los que las expectativas son conseguir una plena integración en la sociedad francesa. Una especie de compromiso entre religión y secularismo es, por lo tanto, imprescindible para ellos. La religión deja de servir como reafirmación de los vínculos con los países de origen para convertirse en un vehículo de expresión de la distinción beur frente a la cultura francesa. Como afirma Bilgrami, "los musulmanes toman su compromiso con el Islam no sólo como uno más entre otros valores, sino también como algo que en sí mismo puede diferenciarse en una serie de compromisos negociables" (824).

La visita a los países del Magreb es un paso importante en la búsqueda de identidad de los

\footnotetext{
${ }^{16}$ Hospitalité Française. Racisme et Immigration Maghrébine (Paris 1984).
} 
personajes de la segunda generación, experimentada casi como un rito iniciático. El retorno a sus raíces culturales, no obstante, se prueba como un estado transitorio. Por ejemplo, Zeida intenta encontrar la vertiente árabe de su personalidad al visitar a sus parientes en Marruecos. Su ideal es llegar a ser una auténtica mujer árabe, pero el sueño se convierte en pesadilla cuando se da cuenta de que es incapaz de comprender el comportamiento de las mujeres marroquíes. Además, allá donde va es recibida como "la chica europea". Su determinación de llegar a ser una áuténtica árabe se estrella contra la definición que el Otro le impone: ella es una extranjera, a pesar de todo. Al final de la narración, Zeida comprende que no es suficiente vestir como una mujer marroquí y sacar agua del pozo como ellas para convertirse en otra persona. Mitad árabe, mitad francesa, Zeida finalmente acepta que el exilio le acompañará a donde quiera que vaya. El único camino viable es asumir sus propias contradicciones. Este sentimiento de permanente exilio es reafirmado con el testimonio escrito de Leila Sebbar en su autobiografía Lettres Parisiennes, donde la autora refleja su alma, constantemente dividida: "Soy una mujer en exilio, siempre a un lado y al otro, en contínuo desequilibrio." 17

El resultado final de la compleja búsqueda de identidad de esta joven generación es el surgimiento de la nueva categoría étnica "beur". Las consecuencias de la interacción entre el Yo y el Otro, en este caso, no son ni la aculturación ni la asimilación sino una forma de pan-etnia que comprende una multiplicidad de grupos étnicos en sí misma. Éste es un fenómeno exclusivo de los jóvenes inmigrantes, sobre el que sus padres se sienten confusos y escépticos, como cuando la madre en Parle mon fils confunde el vocablo "beur" con la palabra francesa "beurre", y se pregunta si tendrá algo que ver con la palabra árabe "tierra" (28). El papel de instituciones como Radio Beur es decisivo a la hora de reforzar el sentido de pertenencia a la comunidad entre los jóvenes magrebíes en Francia. Cuando el hijo en la novela de Sebbar -y miles de jóvenes como él- llama a la cadena radiofónica para expresar su opinión está realizando una aserción explícita de identidad.

A pesar de esta fuerte tendencia pan-étnica, la última moda entre los propios jóvenes magrebíes en Francia es llamarse a sí mismos con designaciones híbridas del tipo "francoargelinos", "árabes franceses", y "jóvenes procedentes de la inmigración norteafricana." 18 En Les A.N.I. du 'Tassili', la distinción entre argelinos de Argelia y argelinos de Francia ya se observa, siendo el argumento que origina una gran pelea entre algunos pasajeros en el barco (157).

\section{La joven generación: recreando identidad}

Allí donde la realidad cultural se compone de elementos híbridos surge la cuestión de la "autenticidad". ¿Qué significa ser un árabe "auténtico" en estas novelas? La respuesta

${ }^{17}$ L. Sebbar y N. Huston, Lettres Parisiennes. Autopsie de l'Exil (Paris 1986) 30.

${ }^{18} \mathrm{~J}$. Gross et alii, "Rai, Rap, and Ramadan Nights. Franco-Maghrebi Cultural Identities", Middle East Report (Sept-Oct 1992) 14. 
depende del contexto en el que se desarrolla la acción. Cuando el personaje se enfrenta a la sociedad francesa, rasgos externos como el color de la piel o la vestimenta se convierten en factores definitorios. No importa cómo el personaje se perciba a sí mismo, porque su cuerpo delata que es un árabe, un magrebí. Por otro lado, reafirmar la propia identidad étnica subrayando los rasgos externos diferenciadores (la polémica decisión de usar el velo es un ejemplo) se convierte en un camino de doble sentido que parte de la percepción del Otro y termina incorporándose al discurso propio. En Parle mon fils, la madre describe su ideal de mujer, que se corresponde con el arquetipo de mujer árabe y contrasta fuertemente con el tipo de mujer francesa que gusta a su hijo: pelo negro, largo y liso; pestañas negras y largas igualmente; ojos negros -nunca azules, porque azules son los ojos del diablo; anchas caderas y fina cintura, son, entre otras, las características de las mujeres de su raza (41).

Sin embargo, cuando los personajes se enfrentan a la sociedad de sus países de origen, rasgos no físicos establecen la diferencia: "Dime, cuando de nuevo abandonaste Argelia, ¿fue porque no pudiste aguantar la mirada de tus hermanos? ¿Fue porque éstos ya no pudieron reconocerte? (Chraibi:115). La incapacidad de comunicarse en lengua árabe, la no observancia de los preceptos de la religión musulmana, o las costumbres aprendidas en Francia se convierten en barreras que imposibilitan la completa identificación con los hermanos. La experiencia del exilio ha transformado a estas personas en una suerte de árabes distintos de los "verdaderos". Mientras que la sociedad francesa se empeña en identificarlos simplemente como árabes o norteafricanos, los inmigrantes no ignoran que se ha abierto una brecha entre ellos y sus compatriotas. Apartados tanto de la sociedad francesa como de la magrebí, la única solución posible para estos inmigrantes es recrear su propia identidad, como Omar de la Garenne-Colombes defiende: "No está al alcance de todos vivir inventando países, historias, pesadillas, sueños, la vida y a uno mismo" (Tadjer:175). Su propia auto-definición en la novela, "Árabe No Identificado", es la consecuencia de esta invención. Como Omar, otros personajes beurs deciden que no existen para ellos identidades absolutas, que las definiciones categóricas que les imponen tanto los franceses como sus compatriotas carecen de sentido. Su identidad es recreada a partir de algunos elementos rememorados de la cultura paterna y, sobre todo, a partir de su imaginación y las circunstancias que los rodean. Así entendemos que Omar manifieste abiertamente su alienación con respecto a la generación de sus padres, estableciéndolos incluso como un grupo étnico diferente de "Tos, negros, algunos vestigios de inmigración Rital y nosotros, los A.N.I.s" (15). O que Zeida, al acercársele un viejo magrebí en la calle, diga: "no, yo no soy árabe, no soy nada, sólo soy yo misma" (Houari:15).

El debate entre identidad y autenticidad se salda en estos relatos a favor de la primera. Los personajes beurs entienden que la autenticidad es la posibilidad de ser lo que, en cierta medida, ya son, y el grado alcanzado dependerá siempre de los ojos ajenos. La identidad, en cambio, es para ellos la libertad de ser lo que quieren ser, de re-memorarse y re-crearse, superando las particularidades de la etnia, la nacionalidad, la tribu, incluso la experiencia personal. 


\section{Conclusión}

En este estudio aplicamos las nuevas teorías que definen la etnia como un constructo social condicionado por el contexto, a algunas obras pertenecientes a la literatura magrebí de expresión francesa. Esta línea teórica nos lleva a plantearnos una serie de preguntas sobre la identidad de las minorías inmigrantes, algunas de las cuales se reflejan en las novelas analizadas: ¿cúales son los procesos mediante los cuales la identidad étnica es creada o destruída, reforzada o debilitada? ¿Hasta qué punto son la identidad y la organización étnicas resultado de un proceso interno? ¿En qué medida son motivadas y definidas por agentes externos? ¿Cúales son los límites de la identidad volicional, en oposición a la prescrita?

Dos voces se entrelazan en los contextos literarios estudiados: el narrador, que describe la dislocación de la identidad en el exilio, y los personajes, cuyo dilema es conseguir la integración sin ceder a la aculturación. Ambos reflexionan sobre el desplazamiento y el desarraigo en las novelas e intentan reconciliar la expresión del colonizador con la del colonizado. Los autores, reafirmándose en un espacio cultural interseccional entre Oriente y Occidente, conducen a sus personajes a la posición imaginaria desde la que ellos mismos escriben y en la que la búsqueda de la identidad alcanza una perpectiva de contrapunto. Oriente y Occidente encuentran expresión en el discurso de los protagonistas, que unas veces ceden ante la presión de la representación ajena y otras ejercen la libertad de elegir, rememorar y recrear sus propias identidades.

Como colofón y para ilustrar la universalidad del fenómeno debatido, rescatamos unos pasajes de la novela de Salman Rushdie Los Versos Satánicos, similar producto de la descolonización y la diáspora: ${ }^{19}$

El hombre que decide cambiarse a sí mismo asume el papel del Creador, según una cierta manera de ver las cosas; es antinatural, es blasfemo, abominación de abominaciones. Desde otro ángulo, también podías ver patetismo en él, heroísmo en su lucha, en su voluntad de arriesgarse; no todos los mutantes sobreviven. $\mathrm{O}$, considerándolo desde el punto de vista sociopolítico: la mayoría de los emigrantes aprenden y pueden convertirse en disfraces. Nuestras propias falsas descripciones para contrarrestar las falsedades inventadas sobre nosotros esconden, por razones de seguridad, nuestra personalidad secreta (53).

La criatura se dominó. "La cuestión es que algunos de nosotros no queremos seguir tolerándolo -dijo con vehemencia-. Saldremos de aquí antes de que nos conviertan en algo peor. Noche tras noche, siento que otra parte de mí empieza a cambiar. (...)

"Pero, ¿cómo lo hacen?", inquirió Chamcha.

"Nos describen -susurró el otro solemnemente-. Eso es todo. Tienen el poder de la descripción, y nosotros sucumbimos a las imágenes que ellos trazan" (167).

${ }^{19}$ Madrid 1989. 